\author{
Vasiuta Viktoriia \\ $\mathrm{PhD}$, Associate professor \\ Department of Economics, Entrepreneurship and Marketing \\ National University «Yuri Kondratyuk Poltava Polytechnic» \\ Poltava, Ukraine \\ ORCID 0000-0002-7469-3968
}

\title{
ENERGY CONSERVATION STRATEGIES AT UKRAINIAN ENTERPRISES
}

Energy development has a decisive influence on the state of the economy in the country and the standard of living of the population. The aim of the welfare state, which, according to the Constitution, is Ukraine, is to provide conditions for increasing the well-being of citizens.

One of the most important components of well-being in civilized states is to provide citizens and companies with the necessary energy resources. The key to achieving this goal should be reliable, economically sound and environmentally friendly meeting the needs of the population and the economy in energy products [1].

Instead of providing the extensive development that Ukraine's economy has been moving through for decades, the energy sector should move to effectively ensure sustainable economic development. Maintenance of the economy and social sphere of the country with the main types of energy resources and raw materials for the needs of the chemical and metallurgical industry rests on the fuel and energy complex of Ukraine.

An energy strategy is an integrated model of state action aimed at achieving national security goals and meeting the energy needs of society at the lowest total cost, while being economically justified. Thus, the Energy Strategy of Ukraine is intended to determine the vector of development of energy sectors of the country in accordance with the goals and objectives of the fuel and energy complex. The objectives of the Energy Strategy are [2] (Fig. 1):

Realization of these goals will create conditions for intensive development of the economy and raising the standard of living of the population of the country.

The main directions of implementation of the Energy Strategy are (Fig.2):

Changes in approaches to the formulation of states' energy policy are taking place in the world: the transition from the outdated model of functioning of the energy sector to the new model. The old model was dominated by large producers, inefficient networks, flawed competition in the markets of natural gas, electricity, and coal. The new model creates a more competitive environment that balances development opportunities and minimizes the dominance of one of the types of energy production or sources and / or fuel delivery routes 
At the same time, it is preferable to increase energy efficiency and the use of energy from renewable and alternative sources. Climate change prevention and adaptation is also one of the priorities of global energy development [2].

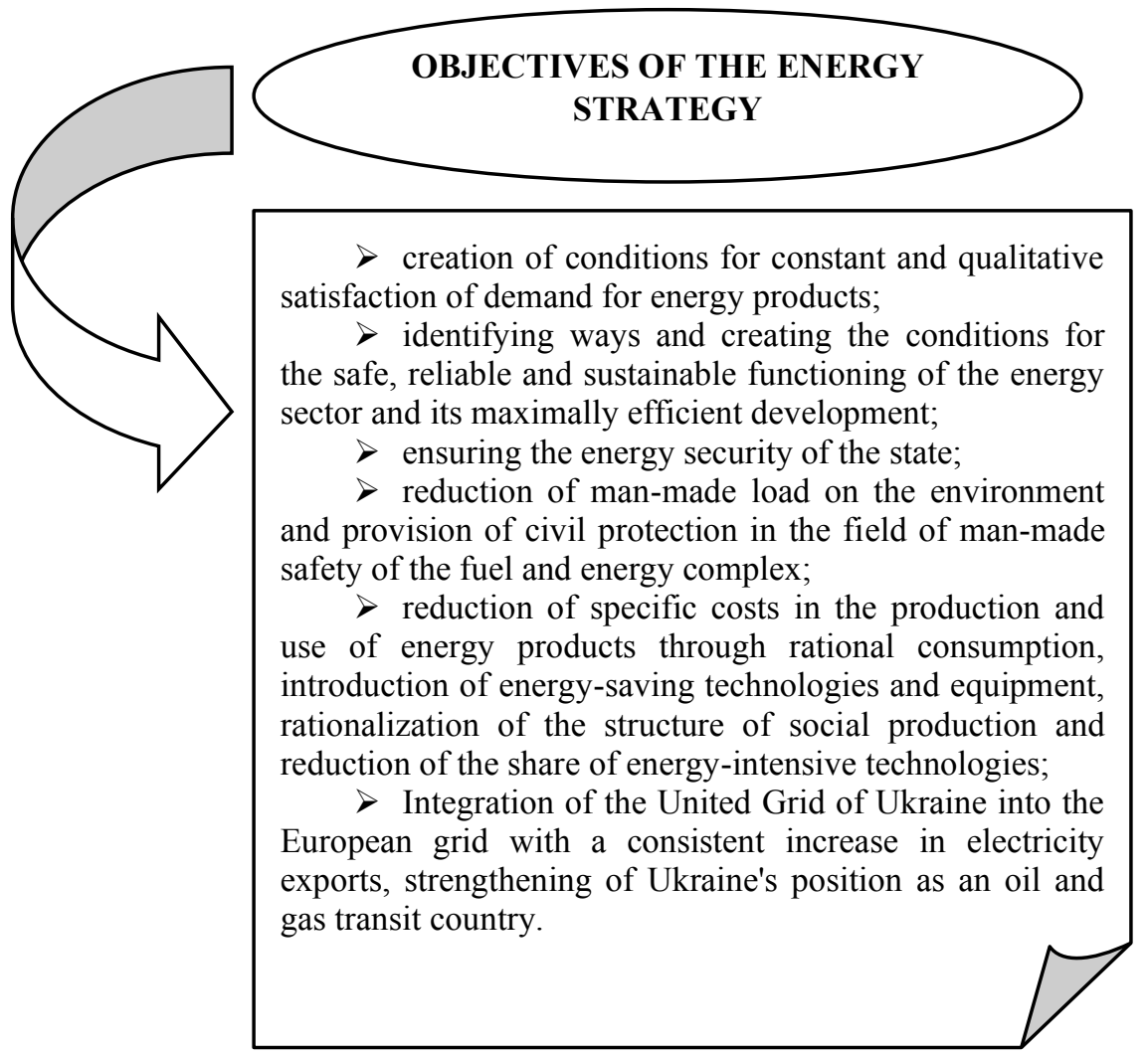

Fig. 1 - Objectives of the Energy Strategy

This poses new economic and technological challenges for Ukraine, but at the same time opens up new opportunities for finding and implementing innovative developments in the field of production, processing of fossil fuels, production, transformation, supply and consumption of energy, which necessitates the formation of a new energy policy of the state.

Strategic guidelines for the development of the fuel and energy complex of Ukraine for the period up to 2035 are outlined in the document "Energy strategy of Ukraine for the period up to 2035 "Security, energy efficiency, competitiveness". 

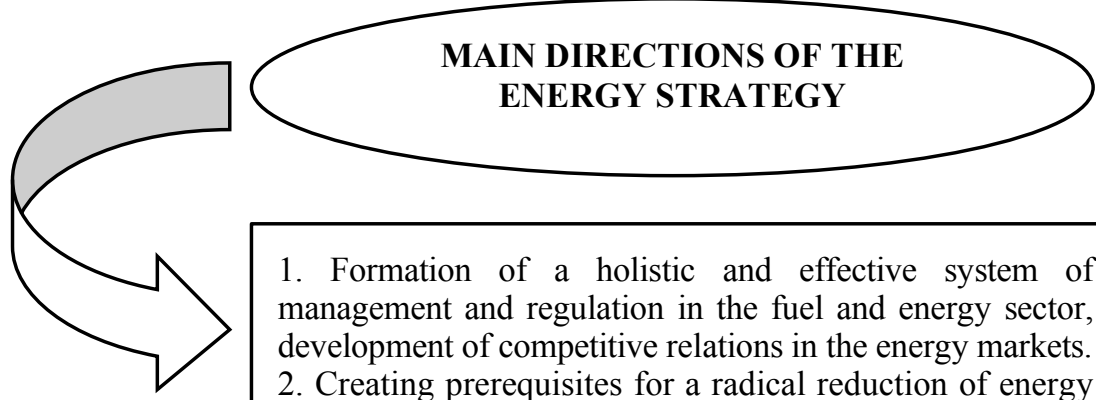

1. Formation of a holistic and effective system of management and regulation in the fuel and energy sector, development of competitive relations in the energy markets. 2. Creating prerequisites for a radical reduction of energy consumption of domestic products through the introduction of new technologies, advanced standards, modern systems of control, management and accounting at all stages of production, transportation and consumption of energy products; development of market mechanisms to stimulate energy saving in all sectors of the economy.

3. Development of export potential of energy, mainly due to electricity, through modernization and renewal of generating capacities, transmission lines, including interstates.

4. Development of the national power engineering, instrumentation and energy complex as a prerequisite for competitiveness of Ukrainian enterprises in energy projects.

5. Optimization of production of own energy resources, taking into account their offers on foreign markets, price and geopolitical situation, increase of volumes of energy and energy products extracted from non-traditional and renewable energy sources.

6. Diversification of external sources of supply of energy products, as well as diversification of routes of their transportation.

7. Creation of a unified state system of statistics, strategic planning, monitoring of production and consumption of energy products, formation of balances of their supply and demand.

8. Balancing the energy product pricing policy, which should cover the cost of their production and create the right conditions for the reliable functioning and sustainable development of the fuel and energy enterprises.

Fig. 2 - Main directions of implementation of the Energy Strategy 
It envisages that by 2025, the reform of Ukraine's energy complex will be largely completed, priority targets for safety and energy efficiency will be achieved, and its innovative renewal and integration with the EU energy sector will be ensured. The main directions of increasing the energy efficiency of the Ukrainian economy have been identified (Fig. 3) [2].

Structural change will have a decisive impact on the overall energy efficiency of the economy. However, measures of general economic impact are also needed, which require separate analysis within the framework of the state's economic strategy. Taking into account the current situation in the field of energy efficiency, the main tasks for the economy as a whole and in the economic sectors for the defined strategic planning period have been defined (Fig. 4) [2].

Energy efficiency and energy conservation are the means of ensuring the efficiency of both business and the state as a whole [3].

Energy conservation is a complex of organizational, legal, industrial, scientific, economic, technical and other measures aimed at rational use and economical consumption of fuel and energy resources [3].

Priority directions and measures for improvement of energy efficiency and energy conservation in Ukraine are [4]:

- reduction of unit costs for energy unit production;

- reduction of the share of energy losses during transportation to consumers per unit of output;

- reduction of energy and energy consumption per unit of output;

- saving energy and energy consumption.

Consider the essence of the main concepts of the strategy of energy saving in the Ukrainian economy sectors (Table 1):

- fuel and energy complex;

- industry;

- housing and communal services;

- transport;

- construction;

- agriculture. 


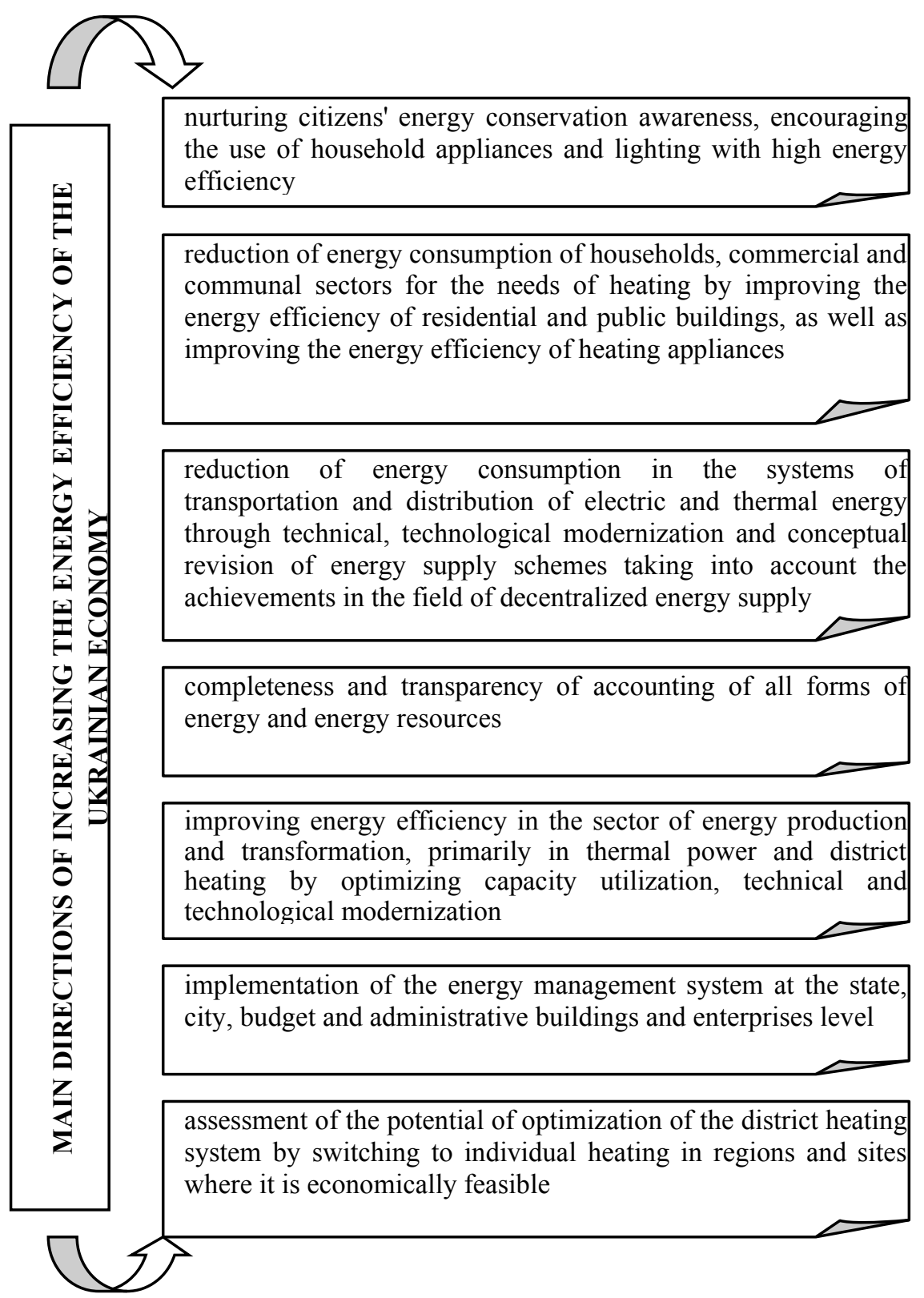

Fig. 3 - Main directions of increasing the energy efficiency of the Ukrainian economy 


\section{Economics Energy Efficiency: Problems of Nowadays and of the Future}

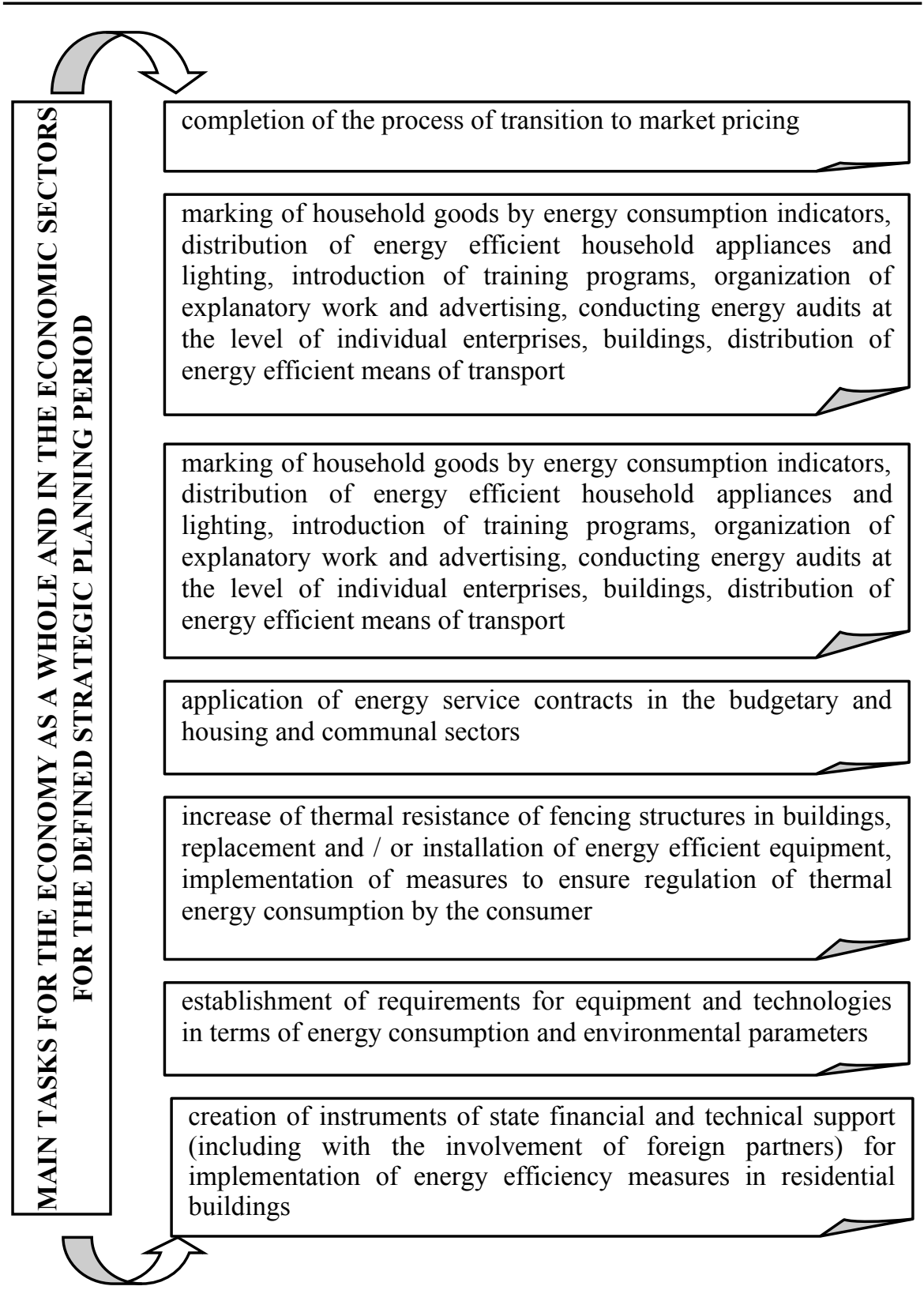

Fig. 4 - Main tasks for the economy as a whole and in the economic sectors for the defined strategic planning period 
Table 1 - Main directions of energy conservation strategy

\begin{tabular}{|c|c|}
\hline $\begin{array}{l}\text { THE ECONOMY } \\
\text { OF UKRAINE }\end{array}$ & $\begin{array}{l}\text { MAIN DIRECTIONS OF THE ENERGY } \\
\text { RESOURCES CONSERVATION STRATEGY }\end{array}$ \\
\hline $\begin{array}{c}\text { Fuel and energy } \\
\text { complex, by directions: }\end{array}$ & $\begin{array}{l}\text { generating the required amount of energy and energy } \\
\text { resources while reducing unit costs }\end{array}$ \\
\hline Electricity & $\begin{array}{l}\text { introduction of new technologies of energy production; } \\
\text { forecasting the balances of produced and consumed } \\
\text { energy; clear implementation of power system } \\
\text { operating modes; organizational measures }\end{array}$ \\
\hline Coal industry & $\begin{array}{l}\text { reducing the cost of transporting coal to consumers; } \\
\text { introduction of new technologies for coal production; } \\
\text { forecasting the balance of coal produced and } \\
\text { consumed; clear implementation of technological } \\
\text { regimes of coal production; organizational measures }\end{array}$ \\
\hline Oil and gas industry: & $\begin{array}{l}\text { reducing the cost of transporting oil and gas to } \\
\text { consumers; introduction of new technologies of oil and } \\
\text { gas production; forecasting the balance of production, } \\
\text { purchase, processing and consumption of oil and gas; } \\
\text { clear implementation of technological modes of } \\
\text { transportation and production of oil and gas; } \\
\text { organizational measures }\end{array}$ \\
\hline $\begin{array}{l}\text { chemical and } \\
\text { etrochemical industry }\end{array}$ & $\begin{array}{l}\text { reduction of energy consumption and energy resources } \\
\text { per unit of output }\end{array}$ \\
\hline $\begin{array}{l}\text { Industry, } \\
\text { by directions: }\end{array}$ & $\begin{array}{l}\text { reduction of energy consumption and energy resources } \\
\text { per unit of output; forecasting the development of } \\
\text { economic sectors; implementation of state programs in } \\
\text { the most promising sectors of the economy; } \\
\text { introduction of new energy-saving technologies of } \\
\text { production and provision of services; } \\
\text { organizational measures aimed at saving energy } \\
\text { resources and types of energy; total accounting of } \\
\text { energy use and energy resources; the widespread use } \\
\text { of energies produced by non-traditional methods }\end{array}$ \\
\hline metallurgy & $\begin{array}{l}\text { a significant reduction in the use of energy and energy } \\
\text { resources per tonne or hryvnia produced }\end{array}$ \\
\hline $\begin{array}{l}\text { building materials } \\
\text { industry }\end{array}$ & $\begin{array}{l}\text { reduction of energy and energy costs in the production } \\
\text { of cement, masonry, precast concrete, concrete } \\
\text { structures and other products; increasing the degree of } \\
\text { recycling of secondary energy resources; introduction } \\
\text { of modern systems of accounting and control of energy } \\
\text { resources }\end{array}$ \\
\hline
\end{tabular}




\begin{tabular}{|c|c|}
\hline \multicolumn{2}{|r|}{ Continuation of Table 1} \\
\hline Utilities & $\begin{array}{l}\text { reduction of specific heating costs of } 1 \text { cubic meter. } \\
\text { buildings and } 1 \text { cubic meter. consumption of cold and hot } \\
\text { water }\end{array}$ \\
\hline Transport & $\begin{array}{l}\text { use of highly efficient motor fuels and their alternative } \\
\text { types; } \\
\text { improvement of the road economy, in particular } \\
\text { motorways and railway tracks; } \\
\text { improvement of the transportation system }\end{array}$ \\
\hline Building & $\begin{array}{l}\text { reduction of energy consumption and energy resources by } \\
1 \text { sq.m. commissioned housing, through the introduction } \\
\text { of new energy-conservation technologies and materials; } \\
\text { transition to energy efficient construction and energy } \\
\text { conservation structures; } \\
\text { changes in the typology of buildings and structures to } \\
\text { ensure qualitative changes in construction and a sharp } \\
\text { reduction in the energy intensity of the industry }\end{array}$ \\
\hline $\begin{array}{l}\text { Agronomy, } \\
\text { by directions: }\end{array}$ & $\begin{array}{l}\text { reduction of energy and energy consumption per tonne of } \\
\text { product produced and use of non-traditional and } \\
\text { renewable energy sources }\end{array}$ \\
\hline plant growing & $\begin{array}{l}\text { improving the structure of tractors and self-propelled } \\
\text { machinery; } \\
\text { rationalization of their energy supply levels; } \\
\text { expanding the use of combined machines and units; } \\
\text { the transition from traction to traction-driven cars, etc. }\end{array}$ \\
\hline stockbreeding & $\begin{array}{l}\text { expand the use of energy-conservation technologies and } \\
\text { equipment for the preparation and distribution of feed; } \\
\text { the use of refrigeration high-efficiency heat exchangers } \\
\text { for the primary processing of milk and the creation of a } \\
\text { microclimate in the premises, as well as economic lamps } \\
\text { and irradiators of animals }\end{array}$ \\
\hline
\end{tabular}

It is proposed to use new and unconventional energy sources - wind, sun, biogas plants for the production of electrical and thermal energy [4].

The main result of the implementation of the strategy in the above sectors is to reduce the use of electricity and energy per unit of production or the hryvnia spent.

The analysis of the process of developing and implementing energy saving strategies at Ukrainian enterprises has shown the following.

The choice of the energy saving strategy of an enterprise is influenced by both internal factors of the enterprise (its internal environment, including available resources and competences), and the state of the external environment (macro and micro environment) [4]. 
The energy conservation strategy of an industrial enterprise is formed under the influence of many factors, which can be divided into two groups (Table 2).

Table 2 - Factors influencing the energy conservation strategy of an industrial enterprise

\begin{tabular}{|c|c|c|c|}
\hline \multicolumn{4}{|c|}{$\begin{array}{l}\text { FACTORS INFLUENCING THE ENERGY CONSERVATION } \\
\text { STRATEGY OF AN INDUSTRIAL ENTERPRISE }\end{array}$} \\
\hline \multicolumn{2}{|c|}{ External } & \multicolumn{2}{|c|}{ Internal } \\
\hline $\begin{array}{c}\text { Macro } \\
\text { environment } \\
\text { factors }\end{array}$ & $\begin{array}{l}\text { Microenvironmental } \\
\text { factors }\end{array}$ & & $\begin{array}{l}\text { Strategic potential } \\
\text { of the enterprise }\end{array}$ \\
\hline $\begin{array}{l}>\text { economic, } \\
\text { natural, } \\
\text { technical, } \\
>\text { political, etc.; } \\
\text { possibilities } \\
\text { of state support } \\
\text { of } \\
\text { implementation } \\
\text { of energy saving } \\
\text { measures of the } \\
\text { enterprise }\end{array}$ & $\begin{array}{l}>\text { consumer } \\
\text { requirements for } \\
\text { products, } \\
>\text { politics of } \\
\text { energy conservation } \\
\text { competition, } \\
>\text { conditions of } \\
\text { supply of energy } \\
\text { resources and } \\
\text { energy saving } \\
\text { equipment }\end{array}$ & $\begin{array}{l}\text { The concept of } \\
\text { enterprise } \\
\text { development, } \\
\text { its strategic } \\
\text { goals defined } \\
\text { by the overall } \\
\text { corporate } \\
\text { strategy }\end{array}$ & $\begin{array}{l}>\text { raw material } \\
\text { resources, } \\
>\quad \text { production, } \\
>\quad \text { labor, } \\
>\text { investment, } \\
>\text { innovative, } \\
>\text { organizational } \\
\text { and managerial, } \\
>\quad \text { financial }\end{array}$ \\
\hline
\end{tabular}

Based on the methodology of the Plan-Do-Check-Act (PDCA) continuous improvement cycle, which is provided for in the International Standard ISO 50001: 2018 Energy management systems - Requirements with guidance for use, an important step in choosing an energy saving strategy is to conduct a strategic energy analysis. This analysis will include studies of external and internal factors that influence the energy consumption and energy efficiency of the enterprise [5].

With the rest of the rocks, you will have to nudge on the need for an energetic audit of industrial production. Its purpose is a technical and economic survey of the systems of transportation and consumption of energy resources and water in order to identify and economically justify the technical, organizational, economic, operational ways of reducing the consumption of primary energy resources. This will maximize the transition to secondary and alternative energy sources, enabling the company to achieve real and significant cost conservation and reduce environmental footprint on the environment. [5].

The implementation of the strategy in concrete actions is possible through a qualitative system of programs, projects and energy saving plans. The implementation of the planned energy conservation measures requires the use of technical, economic, organizational, legal and other methods. 
The enterprise must ensure that energy efficiency indicators are monitored, measured and analyzed. Based on them, conclusions are drawn about the effectiveness of the chosen strategy, carry out corrective actions, revise the overall development strategy and energy policy if necessary.

Achieving the system of goals within the chosen energy saving strategy will ensure the most efficient use of energy resources, will contribute to the stable functioning of the industrial enterprise. These are the priority areas for shaping its economic security [5].

In the majority of Ukrainian enterprises, the development of energy efficiency and energy conservation is low in legal, economic, organizational and technical codes [6].

It is not possible to clearly classify them, because they are interconnected and have a causal nature. Therefore, it is proposed to conditionally distinguish the following obstacles: financial, social, industrial, market (Fig. 5) [7].

It should be borne in mind that high energy consumption during production, energy security issues, ever-changing energy prices, the need to switch to a resource-saving business model pose risks and problems for energy efficiency for businesses [6].

Among the main ones are:

- deterioration in financial performance as fuel and energy prices rise;

- decline in production in case of unreliable supply of energy;

- deterioration of the reputation of the company, which did not live up to expectations in the field of energy efficiency;

- additional costs for compensation of penalties.

Nowadays, Ukrainian enterprises are at different stages of adaptation to the risks associated with energy efficiency [6]. Modern monitoring and response tools have already begun to be used in energy-intensive industries.

The consequences of energy-related events (eg sudden tariff hikes, power outages, poor energy performance) can be critical for companies in different sectors of the economy. 


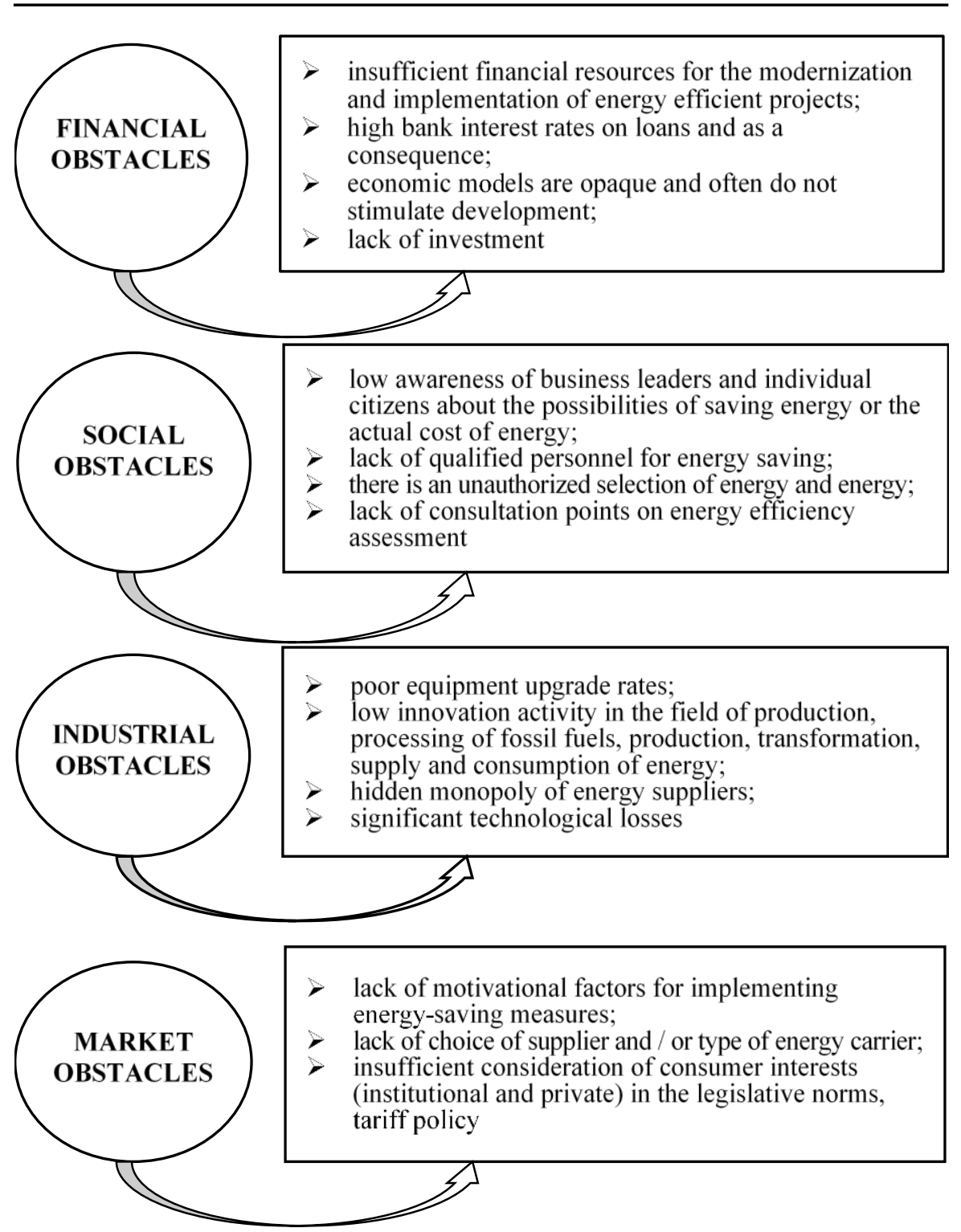

Fig. 5 - The main obstacles to improving energy efficiency in Ukrainian enterprises 
Issues of energy efficiency left unattended pose a serious threat to the normal functioning of the business [6].

Having a detailed energy strategy, including an action plan, and optimal project financing schemes, will help Ukrainian businesses respond to energy challenges and minimize risks associated with energy supply and energy efficiency [3].

Reforms, de-monopolization, transparency and improvement of legal and regulatory mechanisms should be a prerequisite for attracting energy-saving investments [7].

So, for Ukraine today, the issue of conservation energy is a top priority. The construction industry was no exception. In the face of an acute shortage of energy resources in Ukraine, the need to reduce energy consumption in the construction and operation of buildings and structures is a top priority at various state levels.

The construction industry is an energy intensive industry, especially in the construction materials sector. Energy conservation in construction plays an important role, as reducing electricity and heat consumption will reduce the cost of purchasing resources. To date, energy conservation contributes to the improvement of the ecological situation, both in our country and around the world [3].

Energy intensity of production is the amount of energy and fuel consumption for the basic and auxiliary technological processes of production, performance of works, provision of services on the basis of a given technological systems.

The problems of research of energy saving policy in the field of construction are devoted to the work of both domestic and foreign scientists. On the basis of study, analyses, rethinking of their developments, scientific aspects of this problem were formed. Modern concepts for the selection and implementation of effective energy-saving measures in the construction industry are presented in different approaches and directions. This problem is reflected in the writings of many scientists. The theoretical propositions justified by them are a methodological basis for bringing energy consumption in the field of construction to the present world level [3].

Analysis of energy saving trends in construction industries confirmed that the main purpose of construction enterprises is to identify energy saving resources. For this purpose, a comprehensive or partial energy survey of enterprises is conducted with the creation of sound ways to improve the energy efficiency of construction production. In the face of a constant shortage of fuel resources in Ukraine, the problem of reducing energy consumption in the construction and operation of buildings and structures is a state task.

In the current conditions of functioning of the enterprises of the construction industry there is an urgent need to develop a new approach to the management of energy-saving technologies. The construction complex of Ukraine has significant basic resources for implementing an innovative energy-saving policy [3].

Energy conservation in construction is reduced to rational use of energy, reducing unproductive losses. 
The main reasons for the low energy efficiency of construction industry enterprises are (Fig. 6).

Today, there are three main types of energy-conservation measures: organizational measures (internal energy audit, compilation of the energy passport of the enterprise, development of energy-conservation measures and increase of efficiency of technological processes, etc.); technological measures (introduction of energy efficiency standards in the use of industrial buildings, industrial equipment, etc.); investment measures (transition to alternative sources of energy supply and use of modern energy-conservation production technologies) [3].

The choice of one or another energy conservation strategy depends on the goals of the enterprise and its potential capabilities to implement the strategy. One of the main criteria for choosing an energy conservation strategy is to evaluate the cost-effectiveness of the activities undertaken.
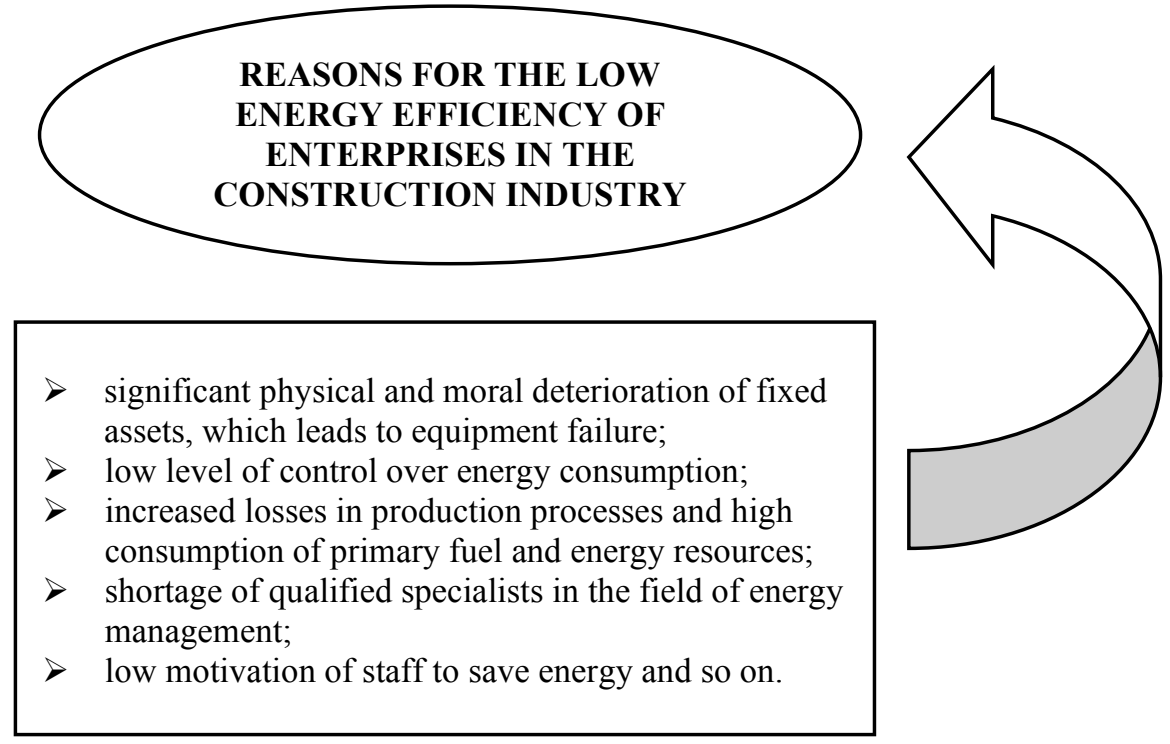

Fig. 6 - The main reasons for the low energy efficiency of enterprises in the construction industry

The implementation of an energy-conservation strategy will help the enterprise to gain a competitive advantage over other entities. The strategy chosen for implementation should be the basis for effective management of energy saving processes in the enterprise.

The expected effects from the implementation of the energy conservation strategy of a construction company may be (Fig. 7). 


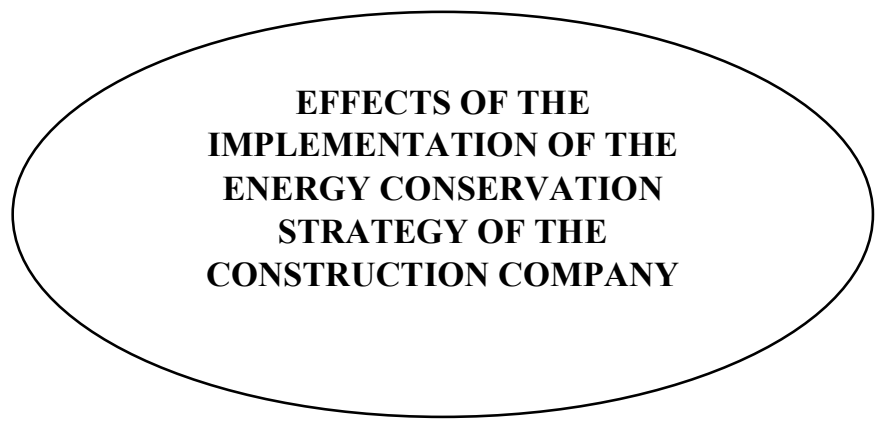

$>$ increase of productivity of equipment, equipment;

$>$ conservation energy and other resources, which leads to lower material costs and cost of production;

$>$ reduction of payments for environmental pollution by reducing the amount of spent fuel and energy resources and others.

Fig. 7 - Effects of the implementation of the energy conservation strategy of the construction company

But these positive results can be accompanied by negative ones for the company. Namely, the increase in the total volume of fixed assets of the enterprise, material costs (despite the conservation of energy resources), operating costs for the maintenance of energy-conservation equipment, the number of service personnel, etc. [5].

The process of implementing an energy conservation strategy at a construction company should foresee the following steps (Fig. 8) [3]. 


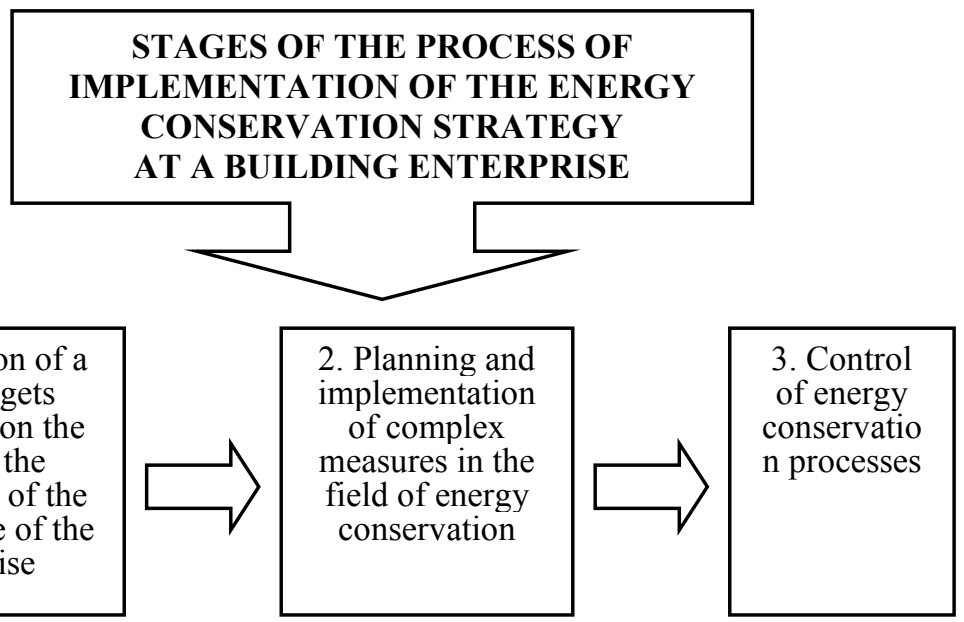

Fig. 8 -Stages of the process of implementation of the energy conservation strategy at a building enterprise

In order to determine the efficiency of use of energy resources in modern construction companies conduct energy audit. According to its results, energysaving technologies are implemented, which ensure the implementation of organizational, legal, technical, technological, economic and other measures aimed at reducing the amount of energy resources [8].

However, in order to achieve the goals of state energy conservation programs and increase the level of energy efficiency in construction, it is advisable to use energy efficient control.

The information generated in the process of energy-efficient control provides an opportunity not only to assess the current state of energy efficiency of a construction company, but also to make effective management decisions to improve energy efficiency.

Implementation of energy-efficient control at construction enterprises is based on the use of the most modern and effective methods and tools, which requires scientific substantiation of organizational and methodological issues [8]. The most actual methodological problems of introduction of energy efficient control have been identified (Fig. 9) [8]. 


\section{Economics Energy Efficiency: Problems of Nowadays and of the Future}
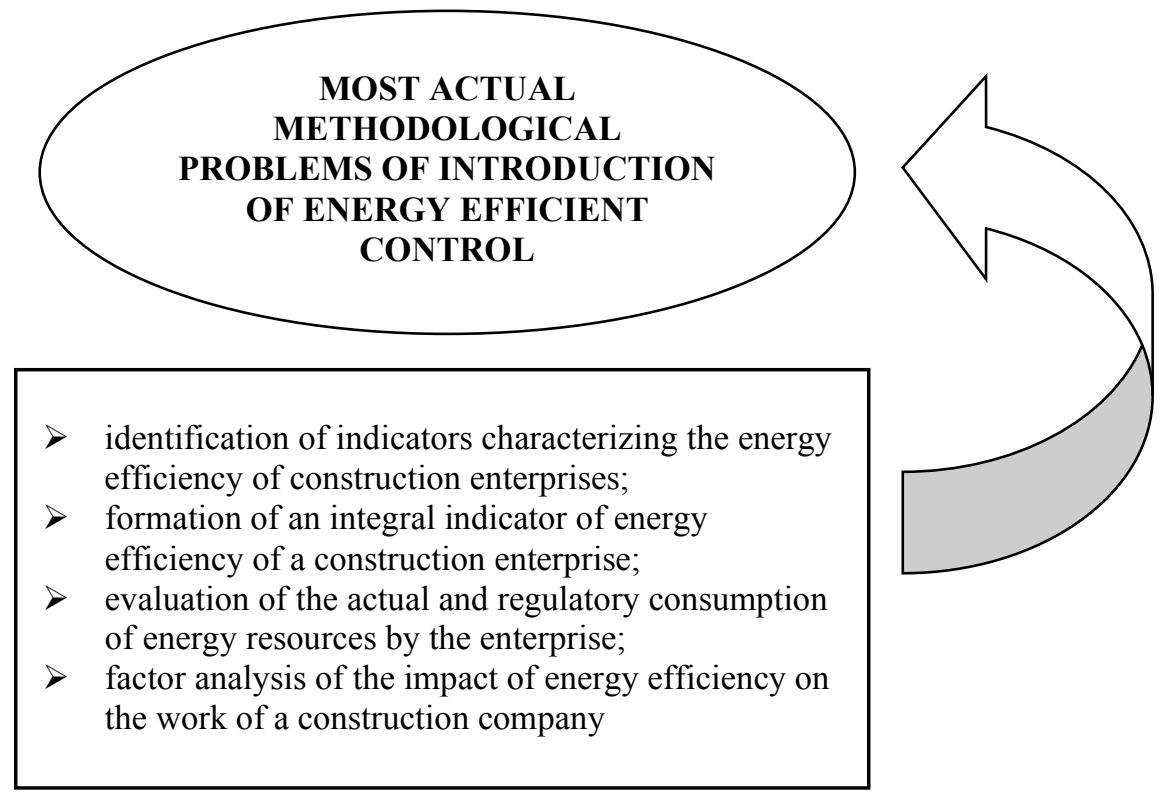

Fig. 9 - The most actual methodological problems of implementing energyefficient control at a construction company

In order to increase the level of energy efficiency of domestic construction companies, it is advisable to develop effective mechanisms for motivating staff, which will increase their competitiveness [9]. Therefore, construction companies in Ukraine need to not only develop and implement energy-efficient production technologies, but also appropriate systems to motivate staff to positively perceive energy-efficient changes and save energy in manufacturing activities.

Effective stimulation of construction companies to efficient use of energy resources and positive perception of energy-efficient changes requires a direct link between the results of activities of all categories of personnel, taking into account energy conservation at each stage of the construction cycle, the use of energyconservation technologies and tangible and intangible assets.

The system of motivation of the personnel of construction enterprises for energy conservation and implementation of energy efficient projects should contain various elements, which make it possible to meet the wide range of needs of the modern worker and develop in him the qualities necessary for the successful functioning of the enterprise. It is suggested to take into account when constructing a model of staff motivation for energy conservation communication and patterns, which are the most important from the point of view of the subject of motivation [9].

An innovative component of the energy-conservation activity of the building complex is the activation of the introduction of new energy-conservation 
technologies, the development of scientifically sound means of organizing and managing the energy-conservation construction process. The choice of efficient energy-conservation technologies and measures, the study of the factors that influence the conservation of energy resources, can only be assessed by the resource provision of innovative energy-conservation activities. This will allow to form an energy conservation strategy for each technological process of a construction enterprise [9].

The analysis of obstacles on the way to efficient energy use in Ukraine has made it possible to determine that the main obstacle is the lack of motivation of all economic entities of the state, control of enterprises and households for energy efficient activities, explaining to citizens the issues of stimulating energy conservation, energy audit and energy management. Therefore, it is advisable to consider the identified threats when developing national and regional development strategies for the future [7].

\section{References:}

1. Vasiuta, V.B. \& Visich, V.V. (2014). Ukraine's Energy Strategy: Objectives and Directions for Implementation. Materialy Vseukrains'koi students'koi Internet-konferentsii "Economic Aspects of Energy Saving: Problems and Solutions" [Materials of the All-Ukrainian Student Internet Conference "Economic Aspects of Energy Saving: Problems and Solutions"] Poltava: PoltNTU, 92-94. [in Ukrainian].

2. Ukraine's Energy Strategy for the Period until 2035 of August 18, 2017 No 605-p. Retrieved from: https://www.kmu.gov.ua/ua/npas/250250456

3. Vasiuta, V.B. \& Vasiuta, V.V. (2019). Energy saving strategies for building enterprises. Zbirnyk naukovykh prats' II Mizhnarodnoi ukraino azerbajdzhans'koi konferentsii «Building Innovations-2019». [Proceedings of the II International Ukrainian-Azerbaijan Conference]. May 2019- Poltava: PoltNTU. 450-452. [in Ukrainian].

4. Ukraine's Energy Strategy: Priority Areas for Conservation Energy. Retrieved from: http://mpe.kmu.gov.ua/minugol/control/uk/publish/article?art_id= 93853\&cat_id $=35082$

5. Sak, T.V. (2016). Enterprise energy conservation strategies: essence, factors, stages of development. Global and national problems of economy,11, 494497. Retrieved from: http://global-national.in.ua/archive/11-2016/104.pdf [in Ukrainian].

6. Seleznova, H.O. (2017). The essence and constituent elements of the energy saving strategy of the enterprise. Economy and society, 13, 711-715. Retrieved from: http://www.economyandsociety.in.ua/journal/13_ukr/121.pdf [in Ukrainian].

7. Byba V.V., Minialenko I.V. \& Vasiuta, V.B. (2019). Barriers to increase energy efficiency in Ukraine. Zbirnyk naukovykh prats' II Mizhnarodnoi ukraino 
azerbajdzhans'koi konferentsii «Building Innovations-2019». [Proceedings of the II International Ukrainian-Azerbaijan Conference]. Poltava: PoltNTU.430-432. [in Ukrainian].

8. Valinkevych, N.V., Dankevich, A.E. (2019). Theoretical and methodological principles of energy conservation management at construction enterprises: concepts, trends, prospects. VISNYK ZhDTU, № 2 (88), 11-16. Retrieved from: https://doi.org/10.26642/jen-2019-2(88)-11-16.

9. Vasiuta, V.B., Ivanytscka, S. B. \& Galayda, T.A. (2019). Formation of the motivation mechanism of energy efficiency changes in building enterprises. Zbirnyk naukovykh prats' II Mizhnarodnoi ukraino azerbajdzhans'koi konferentsii "Building Innovations-2019». [Proceedings of the II International UkrainianAzerbaijan Conference]. Poltava: PoltNTU. 447-449. [in Ukrainian]. 